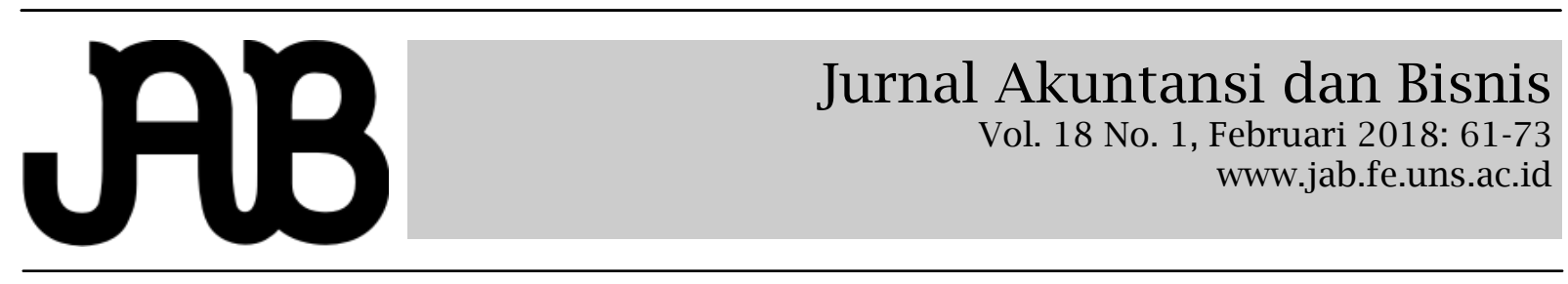

\title{
DIREKSI DAN DEWAN KOMISARIS: PENGARUH DEWAN WANITA TERHADAP KE- BIJAKAN DIVIDEN DI INDONESIA
}

\author{
ELDINAR ISTY FAUZIAH (eldinarif@gmail.com) \\ AGUNG NUR PROBOHUDONO (anprobohudono@staff.uns.ac.id)
}

Program Studi Akuntansi, Fakultas Ekonomi dan Bisnis, Universitas Sebelas Maret, Indonesia

\begin{abstract}
A B S T R A C T
Some of institutional specificities of emerging economies are market uncertainty that may increase agency problems that raise doubts about future cash flows such as dividend payments. This research aims to analyze the impact of board gender diversity on dividend policy in Indonesia. The sample of this research is 37 companies from various industries listed from Indonesia Stock Exchange over the period 20132016. This research is a quantitative research with purposive sampling method. The dividend policy was measured with Dividend Payout Ratio (DIVPR). The evidence indicates that women directors is negatively related to dividend policy, while women commissioners has positive impact. Moreover, we find that women independent directors and women independent commissioners do not have an effect on dividend policy. The sample in this study is limited because the payment of dividends is not an obligation and women are still a minority on board.
\end{abstract}

Keywords: Dividend Payment, Board Gender Diversity, Agency Theory

Beberapa kekhususan institusi negara berkembang adalah ketidakpastian pasar yang dapat meningkatkan masalah keagenan sehingga timbul keraguan tentang arus kas masa depan seperti pembayaran dividen. Penelitian ini bertujuan untuk menganalisis pengaruh keragaman gender terhadap kebijakan pembayaran dividen di Indonesia. Sampel penelitian ini sebanyak 37 perusahaan dari berbagai industri yang terdaftar dari Bursa Efek Indonesia selama periode 2013-2016. Penelitian ini merupakan penelitian kuantitatif dengan metode purposive sampling. Kebijakan dividen diukur dengan Dividend Payout Ratio (DIVPR). .Bukti menunjukkan bahwa direktur wanita berpengaruh negatif terhadap kebijakan dividen, sementara komisaris wanita memiliki pengaruh positif. Selain itu, direktur independen wanita dan komisaris independen wanita tidak berpengaruh pada kebijakan dividen. Sampel dalam penelitian ini terbatas karena pembayaran dividen bukanlah suatu keharusan dan wanita masih merupakan minoritas di jajaran dewan.

Kata kunci: Pembayaran Dividen, Keanekaragaman Gender, Teori Agensi

\section{PENDAHULUAN}

Beberapa tahun terakhir, semakin meningkat keraguan para investor terhadap pengembalian yang diberikan oleh perusahaan terutama di negara berkembang. Negara berkembang cenderung lemah mekanisme kebijakan dan tingginya keterlibatan pemerintah (La Porta, Lopez-de-Silanes, Shleifer, \& Vishny, 2000). Selain itu, ciri lain dari negara berkembang meliputi kurangnya perlindungan hak minoritas, luasnya kepemilikan pemerintah, dan ketidakpastian pasar yang menyebabkan mekanisme peramalan kebijakan tentang pembayaran dividen di negara berkembang sulit diprediksi (Saeed \& Sameer, 2017). Risiko terbesar yang kerap dihadapi oleh manajemen di negara berkembang adalah adanya perubahan ekonomi, aktivitas pesaing, perubahan teknologi, dan perubahan peraturan (Thornton, 2015). Perubahan-perubahan tersebut sangat berpengaruh terhadap keputusan yang akan diambil oleh manajemen. Adanya ketidakpastian pasar menyebabkan risikorisiko tersebut sulit untuk diprediksi menyebabkan adanya keraguan bagi direksi maupun komisaris akankah mengeluarkan kas atau menahan kas untuk 
meminimalkan risiko selama adanya ketidakpastian. Ang, Fatemi, dan TouraniRad (1997) menunjukkan bahwa perusahaan yang memiliki laba yang berlimpah akan memilih untuk menahan laba mereka karena pengembalian yang didapat dari pembagian dividen mungkin tidak sebesar apabila laba tersebut diinvestasikan kembali.

Para pemegang saham berupaya untuk mengurangi adanya masalah agensi ini dengan mendesak perusahaan untuk meningkatkan keragaman gender dalam jajaran dewan perusahaan. Direksi dan komisaris dengan proporsi wanita yang lebih banyak menunjukkan pengelolaan keuangan yang lebih baik pada periode setelah krisis keuangan sebab wanita cenderung mengambil keputusan keuangan yang tepat dengan risiko yang rendah (Ward \& Forker, 2015). Keragaman dewan diharapkan dapat secara efektif memantau untuk mengurangi tindakan penyelewengan wewenang yang dilakukan oleh manajer (Adams \& Ferreira, 2009). Direksi dan dewan komisaris yang beragam akan memiliki lebih banyak variasi ide dan perspektif yang berbeda. Keragaman gender memungkinkan untuk evaluasi pilihan yang lebih menyeluruh karena informasi yang tersedia semakin banyak. Selain itu, keragaman anggota dewan baik direksi maupun komisaris dapat menghasilkan keputusan dengan kualitas yang lebih tinggi (Amason, 1996) dan menghasilkan solusi yang lebih inovatif (Chen, Liu, \& Tjosvold, 2005). Dewan yang beragam akan lebih efektif dalam menangani perubahan organisasi sehingga adanya keragaman akan lebih mampu merespon perubahan dinamis yang cepat di pasar yang tidak pasti (Erhardt, Werbel, \& Shrader, 2003). Selain itu, keberadaan wanita yang lebih banyak di jajaran direksi maupun komisaris dapat meningkatkan reputasi dan berdampak positif terhadap kinerja keuangan, investasi institusional, dan harga saham (Fombrun \& Pan, 2006).

Sebagian besar negara maju memiliki peraturan tata kelola perusahaan yang mendukung perlindungi hak minoritas. Pucheta-Martinez dan Bel-Oms (2016) dengan objek penelitian perusahaan di
Spanyol menunjukkan adanya hubungan positif antara keragaman gender dan pembayaran dividen. Byoun, Chang, dan Kim (2016) juga menemukan bahwa perusahaan-perusahaan di US yang memiliki keragaman gender akan lebih banyak membayar dividen jika dibandingkan dengan perusahaan dengan tingkat keragaman gender yang rendah. Akan tetapi, Saeed dan Sameer (2017) yang dilakukan di beberapa negara berkembang seperti India, China, dan Rusia menunjukkan semakin banyak wanita akan mengurangi pembayaran dividen karena wanita cenderung enggan terhadap risiko. Negara dengan perlindungan investor yang lemah menyebabkan pemegang saham minoritas mendapat dividen lebih rendah daripada negara-negara dimana perlindungan investor relatif kuat (La Porta et al, 2000). Terdapat hasil yang bertentangan dari penelitian sebelumnya maka mendorong penulis untuk meneliti kembali bagaimana pengaruh keragaman gender terhadap kebijakan dividen. Penelitian ini meninjau dari sisi direktur wanita dan komisaris wanita karena Indonesia menerapkan two-tiers system. Dalam two-tiers system terdapat pemisahaan peran antara pengawasan yang dilakukan oleh komisaris dan peran pengelolaan yang dilakukan oleh direksi.

Objek penelitian ini adalah perusahaan di Indonesia. Penerapan twotiers system di Indonesia turut mendorong banyaknya wanita berada di tingkat direksi dan dewan komisaris. Penulis memilih Indonesia karena beberapa alasan, seperti di Indonesia tidak ada peraturan khusus yang mengatur tentang keragaman gender, tetapi keragaman gender di Indonesia merupakan tertinggi di kawasan ASEAN karena menerapkan two-tiers system (Ferry, 2016). Selanjutnya, tingkat perekonomian di Indonesia masih berkembang sehingga memperbesar kekhawatiran perusahaan terhadap arus kas masa depan sehingga mereka akan cenderung menahan kas untuk pendanaan di masa depan.

Lembaga Grant Thornton (2015) menemukan bahwa direktur pria dan wanita melihat risiko dan peluang dari sudut pandang yang berbeda. Terdapat 
stereotip yang mengatakan wanita cenderung tidak berani untuk mengambil risiko dibandingkan pria (Saeed \& Sameer, 2017). Secara umum, pria dianggap lebih kompetitif, percaya diri, dan lebih berani untuk mengambil suatu risiko (Eckel \& Grossman, 2008). Hasil yang bertentangan dikemukakan oleh Adams dan Funk (2012) menemukan bahwa direktur wanita cenderung lebih risk-loving daripada direktur pria. Direktur wanita juga memiliki keunggulan komparatif sehubungan dengan diversifikasi produk dan tugas-tugas yang berhubungan dengan komunikasi (Schubert, 2006). Bukti lainnya bahwa direktur wanita memiliki tingkat sensitivitas lingkungan yang lebih tinggi sehingga meningkatkan aktivitas tanggung jawab sosial perusahaan (Bear, Rahman \& Post, 2010), mengurangi manipulasi laba dan penipuan (Bermig \& Frick, 2010).

Pemegang saham menekankan keberadaan wanita karena adanya anggapan wanita mampu mengerti pemegang saham dengan baik. Kusumastuti, Supatmi, dan Sastra (2007) menemukan wanita lebih berhati-hati, cenderung enggan terhadap risiko, dan teliti. Sikap tersebut dapat mendukung peran komisaris. Komisaris bertugas untuk mengawasi jalannya perusahaan agar sesuai dengan tujuan perusahaan. Memperhatikan kesejahteraan pemegang saham merupakan salah satu tujuan perusahaan. Komisaris wanita dapat memperbesar kemungkinan untuk membagikan dividen, karena komisaris wanita akan menuntut lebih banyak mekanisme kontrol dari tim manajemen serta membuat keputusan lebih baik yang berdampak positif bagi pemegang saham (Adams, Hermalin \& Weisbach 2010). Akan tetapi, apakah dengan keberadaan direksi wanita dan komisaris wanita dapat memengaruhi pembayaran dividen? Penelitian ini akan meguji tentang pengaruh keberadaan wanita di direksi dan komisaris terhadap kebijakan pembayaran dividen.

Setelah pendahuluan, artikel ini akan menjabarkan tentang literatur dan pengembangan hipotesis yang diperkuat dengan hasil penelitian terdahulu.
Selanjutnya, metode penelitian akan menguraikan tentang teknik pengumpulan dan analisis data. Pembahasan hasil juga dijabarkan untuk menjelaskan semua aspek terkait penelitian. Kemudian, kesimpulan, saran, implikasi dan keterbatasan digunakan sebagai penutup dalam penelitian ini.

\section{TIN J A UAN P US TAKA DAN PENGEMBANGAN HIPOTESIS \\ Teori Keagenan}

Teori keagenan berfokus pada konflik yang terjadi pada perusahaan berdasarkan hubungan kontraktual antara prinsipal dan agen (Jensen \& Meckling, 1976). Menurut teori keagenan, manajer memiliki kesempatan untuk menggunakan sumber daya perusahaan untuk kepentingan sendiri, tetapi pemilik juga memiliki wewenang untuk memberikan batasan kepentingan manajer agar hak-hak para pemegang saham terlindungi. Meningkatnya informasi asimetri antara pemilik dan manajemen akan menyebabkan masalah keagenan semakin besar dan menimbulkan keraguan para pemilik terhadap arus kas masa depan.

Salah satu cara untuk mengurangi masalah keagenan ini adalah dengan membagikan dividen. Menurut Jensen (1986), dividen bertindak sebagai mekanisme untuk mengurangi masalah keagenan yang timbul dari konflik antara pemilik dan manajemen. Ang, Fatemi, dan Tourani-Rad (1997) menunjukkan bahwa perusahaan yang memiliki laba yang berlimpah akan memilih untuk menahan laba kemudian diinvestasikan kembali karena pengembalian yang didapat dari pembagian dividen mungkin tidak sebesar apabila laba tersebut diinvestasikan. Jensen (1986) berpendapat bahwa manajer memiliki insentif untuk menggunakan sumber daya organisasi demi keuntungan mereka sendiri ketika mereka menahan kas, daripada menggunakan kelebihan arus kas ini untuk membayar dividen kepada pemegang saham. Oleh karena itu, para pemegang saham mendorong adanya keragaman gender. Keragaman gender dianggap mampu untuk memberikan pemantauan secara efektif kepada 
manajemen sehingga dapat mengurangi masalah keagenan (Adams \& Ferreira, 2009).

\section{Kebijakan Dividen}

Kebijakan pembayaran dividen merupakan salah satu masalah terpenting terkait arus kas bebas. Arus kas bebas adalah arus kas yang melebihi dari yang diperlukan untuk mendanai semua proyek (Jensen, 1986). Kebijakan dividen merupakan pembagian hasil baik dalam bentuk uang tunai maupun saham kepada para pemegang saham. Jensen (1986) menunjukkan dividen dapat mengurangi masalah keagenan. Akan tetapi, Ang Ang, Fatemi, dan Tourani-Rad (1997) menunjukkan bahwa perusahaan yang memiliki laba akan memilih untuk menahan laba mereka karena pengembalian yang didapat lebih besar jika laba diinvestasikan kembali dibandingkan dengan membagikan laba tersebut sebagai dividen.

La Porta et al. (2000) menyajikan model yang menjelaskan kebijakan dividen di pasar negara berkembang. Pertama, menurut outcome model terdapat hubungan positif antara praktik tata kelola dan kebijakan dividen. Jadi semakin baik tata kelola perusahaan maka akan membayarkan dividen lebih tinggi. Dividen dijadikan bentuk pertanggungjawaban perusahaan terhadap pemegang saham. Kedua, menurut substitution model terdapat hubungan negatif antara praktik tata kelola perusahaan dan kebijakan dividen. Jadi, ketika tata kelola perusahaan mereka buruk maka mereka akan meningkatkan dividen yang dibayarkan untuk membangun reputasi dan menarik para investor agar berinvestasi di perusahaan tersebut.

Undang-Undang Nomor 40 Tahun 2007 menjelaskan perusahaan dapat membagikan dividen jika perseroan memiliki saldo laba positif. Perseroan wajib menyisihkan sejumlah kas dari laba bersih setiap tahun untuk dicadangkan minimal 20\% (dua puluh persen) dari jumlah modal yang ditempatkan dan modal yang disetor. Kemudian, seluruh laba bersih setelah dikurangi penyisihan untuk cadangan akan dibagikan kepada pemegang saham sebagai dividen.

\section{Karakteristik Wanita}

Kurangnya perlindungan investor di negara berkembang mendorong pemegang saham meningkatkan upaya untuk melindungi kepentingannya seperti memperbanyak wanita di jajaran direksi (Saeed \& Sameer, 2017). Hal ini disebabkan karena wanita memiliki karakteristik-karakteristik yang dianggap dapat menguntungkan para pemegang saham. Wanita dinilai lebih independen dibandingkan pria karena direktur wanita menjadi kaum minoritas dan sebagian besar berasal dari karir nonbisnis, seringkali mereka naik ke eselon atas dengan menunjukkan kinerja handal dan pendidikan mereka yang mencolok (Hillman, Cannella Jr \& Harris, 2002). Ini menyiratkan bahwa direktur wanita tidak memiliki jaringan koneksi dengan pihak lain. Selain itu, keberadaan wanita biasanya memiliki hubungan yang kuat dengan jaringan masyarakat yang lebih beragam menyiratkan kemudahan dalam mengakses sumber daya (Hillman, Cannella \& Poetzold, 2000). Mudahnya dalam mengakses sumber daya akan mencegah tindakan manajemen untuk menahan kas. Di sisi lain, wanita juga cenderung enggan terhadap risiko (risk aversion). Saeed, Belghitar dan Yousaf (2016) meneliti beberapa negara berkembang dan menemukan bukti bahwa tingkat wanita rendah di perusahaan yang memiliki risiko yang tinggi. Direksi wanita lebih cenderung menahan kas ketika terjadi ketidakpastian pasar (Saeed \& Sameer, 2017). Penelitian terdahulu banyak di lakukan di negara yang menganut onetiers system sedangkan penelitian ini di lakukan di Indonesia yang menganut twotiers system. Oleh karena itu, penelitian ini akan menguji apakah direktur wanita dan komisaris wanita berpengaruh terhadap kebijakan dividen.

\section{Proporsi Direktur Wanita dan Kebijakan Pembayaran Dividen}

Wanita, tampaknya lebih berhati-hati dalam menghadapi risiko. Terdapat banyak faktor yang dapat memperbesar risiko keuangan seperti terjadinya ketidakpastian pasar. Direktur wanita cenderung memilih untuk 
Direksi Dan Dewan Komisaris: Pengaruh Dewan Wanita Terhadap Kebijakan Dividen Di Indonesia (Fauziah dan Probohudono)

menahan kas selama adanya

ketidakpastian pasar untuk melindungi keuangan perusahaan. Risiko terbesar yang kerap dihadapi oleh manajemen di negara berkembang adalah adanya perubahan ekonomi (Grant Thornton, 2017). Perubahan tersebut sangat berpengaruh terhadap keputusan yang akan diambil oleh manajemen. Adanya ketidakpastian pasar menyebabkan risiko tersebut sulit untuk diprediksi sehingga direktur wanita akan cenderung menahan arus kas keluar.

Marter dan Lighthall (2012) berpendapat ketika dihadapkan dengan keadaan yang tidak pasti maka wanita akan cenderung merasa takut sedangkan pria akan cenderung mengeluarkan amarah. Emosi ini memberikan efek bagi perilaku seperti rasa takut mendorong orang untuk berusaha mengurangi risiko sedangkan amarah akan mendorong orang untuk berani mengambil risiko. Cabo, Gimeno dan Nieto (2012) menguji tentang keanekaragaman gender dalam sektor perbankan. Persentase wanita di direksi dalam sektor perbankan dinilai rendah karena sektor perbankan dianggap rentan terhadap risiko. Tingginya risiko terkait pasar di negara berkembang dan kecenderungan keengganan terhadap risiko dari direktur wanita, maka kemungkinan besar mereka akan meminimalkan risiko lingkungan dengan mempertahankan uang tunai dan membayar dividen rendah (Saeed \& Sameer, 2017).

H1: Proporsi direktur wanita berpengaruh negatif terhadap kebijakan pembayaran dividen

\section{Proporsi Komisaris Wanita dan Kebijakan Pembayaran Dividen}

Pemegang saham menekankan keberadaan wanita di jajaran dewan komisaris karena adanya anggapan wanita mampu mengerti pemegang saham dengan baik (Adams \& Ferreira, 2009). Wanita dalam jajaran komisaris dapat membantu pengambilan keputusan yang tepat dengan resiko yang rendah. Keberadaan wanita berpengalaman biasanya memiliki hubungan yang kuat dengan jaringan masyarakat yang lebih beragam menyiratkan keuntungan dalam mempermudah mengakses sumber daya
(Hillman, Cannella, \& Paetzold 2000). Mudahnya akses sumber daya dikarenakan wanita dapat membangun saluran komunikasi dan keharmonisan dengan pemangku kepentingan eksternal untuk mengurangi biaya agensi di tingkat dewan dan memperoleh dukungan serta menciptakan legitimasi di lingkungan eksternal (Adams \& Ferreira, 2009). Kemudahan dalam mengakses modal dapat mencegah tindakan komisaris untuk menahan kas di masa krisis.

Dewan komisaris dengan proporsi wanita yang lebih tinggi menunjukkan pengelolaan keuangan yang superior, sehubungan dengan kualitas pinjaman pada periode setelah krisis keuangan sebab wanita cenderung mengambil keputusan keuangan yang tepat dengan risiko yang rendah (Ward \& Forker, 2015). Komisaris bertugas untuk mengawasi kegiatan operasional perusahaan. Adanya peningkatan jumlah wanita di komisaris maka kemungkinan untuk membayar dividen akan lebih besar karena komisaris wanita akan menuntut lebih banyak mekanisme kontrol serta membuat keputusan lebih baik yang berdampak positif bagi pemegang saham.

H2: Proporsi komisaris wanita berpengaruh positif terhadap kebijakan pembayaran dividen

\section{Direktur Independen Wanita dan Ke- bijakan Pembayaran Dividen}

Para pemangku kepentingan membutuhkan perwakilan di dewan independen untuk melindungi aset mereka. Hillman, Cannella Jr, dan Harris (2002) memberikan bukti bahwa sebagian besar dewan wanita berasal dari karir non-bisnis; seringkali mereka naik ke jabatan atas dengan menunjukkan kinerja profesional dan pendidikan mereka yang mencolok. Ini menyiratkan bahwa direktur wanita tidak memiliki jaringan koneksi dengan pihak lain. Direktur independen lebih konservatif daripada direktur internal dan dapat membantu mengurangi biaya agensi yang timbul dari adanya informasi asimetri antara pemegang saham dan manajer. Direktur independen juga memiliki insentif untuk menetapkan keputusan dengan tepat 
untuk mempertahankan reputasi (Probohudono, Tower \& Rusmin, 2013). Direktur independen dapat membatasi perilaku oportunistik manajer yang seringkali merugikan pemegang saham. Prasanna (2014) menunjukkan direksi independen wanita lebih memilih untuk membayar dividen daripada mempertahankan laba. Oleh karena itu, penulis menduga bahwa semakin banyak direktur independen wanita maka akan meningkatkan pembayaran dividen.

H3: Direktur independen wanita berpengaruh positif terhadap kebijakan pembayaran dividen

Komisaris Independen Wanita dan Kebijakan Pembayaran Dividen

Pihak independen dianggap pengamanan optimal dari nilai pemegang saham dengan memantau secara ketat tim manajemen dan dengan memberikan saran strategis dan kontak bisnis (Andrés, Arranz-Aperte , \& Rodriguez-Sanz 2017). Komisaris independen dapat mengurangi masalah agensi (Sharma, 2011). Adams dan Ferreira (2009) memberikan bukti wanita dapat memantau perilaku manajer dengan efektif daripada laki-laki dengan cara memantau melalui diskusi, komunikasi yang lebih baik dengan karyawan dan wanita mampu menampilkan pemikiran independen yang lebih baik. Hal ini penting dilakukan untuk memeriksa kegiatan oportunistik dan memberikan kontrol yang lebih baik terhadap manajemen (Adams, Hermalin, \& Weisbach, 2010). Komisaris independen kerap melakukan pemantauan langsung dengan sistem pembayaran yang memadai seperti dividen untuk menyelaraskan kepentingan pemegang saham dan manajemen (Holmstrom \& Milgrom, 1994). Oleh karena itu, penulis menduga semakin banyak komisaris independen maka akan membayarkan dividen lebih banyak.

H4: Komisaris independen wanita berpengaruh positif terhadap kebijakan pembayaran dividen

\section{METODE PENELITIAN}

Penelitian ini akan berfokus pada negara Indonesia. Penulis memilih Indonesia karena beberapa alasan. Pertama seperti yang dijelaskan Ferry (2016) bahwa Indonesia tidak memiliki pedoman tata kelola perusahaan yang membahas tentang keragaman gender. Meskipun tidak ada peraturan khusus, Indonesia memiliki tingkat keberagaman gender yang tertinggi karena menerapkan two-tiers system dimana terdapat posisi direksi dan komisaris. Ke dua, tingkat perekonomian di Indonesia masih berkembang sehingga memperbesar kekhawatiran perusahaan terhadap arus kas masa depan sehingga pembayaran dividen cenderung rendah.

\section{Sampel}

Metode pemilihan sampel dalam penelitian ini menggunakan metode purposive sampling dengan kriteria :

1. Perusahaan yang tercatat di Bursa Efek Indonesia pada tahun 2013-2016.

2. Memiliki laba bernilai positif.

3. Membagikan dividen selama tahun 20132016.

4. Perusahaan yang menyajikan laporan tahunan pada tahun 2013-2016

5. Perusahaan menyajikan laporan keuangan dalam mata uang rupiah pada periode 2013-2016.

6. Memiliki direksi dan komisaris wanita.

Penelitian ini bertujuan untuk menguji pengaruh keragaman gender dewan terhadap kebijakan pembayaran dividen pada tahun 2013-2016 yang berasal dari berbagai sektor perusahaan yang tercatat di Bursa Efek Indonesia.

Tabel 1 menunjukkan sampel yang memenuhi kriteria penelitian ada 148 tetapi 10 sampel tergolong data outlier

Tabel 1.

Objek penelitian

\begin{tabular}{lc}
\hline \multicolumn{1}{c}{ Keterangan } & Jumlah \\
\hline $\begin{array}{l}\text { Perusahaan membayar dividen } \\
\text { tahun 2013-2016 secara berturut- } \\
\text { turut }\end{array}$ & 84 \\
Laba berniali negatif & $(6)$ \\
Laporan keuangan dalam US\$ & $(10)$ \\
Tidak menerbitkan laporan tahunan & $(0)$ \\
Tidak memiliki direktur wanita atau & $(31)$ \\
komisaris wanita & 37 \\
Total perusahaan & $\mathrm{x} 4$ \\
Tahun penelitian & 148 \\
Total sampel & \\
\hline
\end{tabular}


sehingga dikeluarkan. Total sampel akhir yang digunakan dalam penelitian ini sebanyak 138 sampel.

\section{Definisi Operasional dan Pengukuran Variabel}

Dividen adalah proses pembagian hasil keuntungan kepada pemegang saham dalam bentuk uang tunai atau saham. Pembayaran dividen yang lebih tinggi kepada pemegang saham dapat mencegah sejumlah uang mengalir ke manajer (BenNasr, 2015). Kebijakan dividen diproksikan dengan dividend payout ratio (DIVPR) seperti yang digunakan dalam Amidu (2006). DIVPR diformulasikan sebagai dividen per saham dibagi laba per saham.

Proporsi direktur wanita (DDW) dirumuskan sebagai jumlah direktur wanita dibagi total anggota direktur. Proporsi komisaris wanita (DKW) dirumuskan sebagai jumlah komisaris wanita dibagi total anggota dewan komisaris. Proporsi direktur wanita (DDIW) dirumuskan sebagai jumlah direktur independen wanita dibagi total anggota direksi. Proporsi komisaris independen wanita (DKIW) diformulasikan sebagai jumlah komisaris independen wanita dibagi total anggota dewan komisaris.

Sebagai variabel kontrol, Firmsize diformulasikan sebagai total aset. ROA diformulasikan laba bersih dibagi total aset. Jenis industri dikelompokkan menjadi 3 jenis industri berdasarkan Bursa Efek Indonesia yang terdiri dari: (1) industri utama, (2) industri manufaktur, dan (3) industri jasa. Variabel ini akan diukur dengan menggunakan variabel dummy. IND1 bernilai 0 dan IND2 bernilai 0 jika termasuk industri utama, IND1 bernilai 0 dan IND2 bernilai 1 jika termasuk industri manufaktur, IND1 bernilai 1 dan IND2 bernilai 0 jika termasuk industri jasa. Industri manufaktur dan industri jasa digunakan untuk menangkap pengaruh industri terhadap pembayaran dividen, sedangkan industri utama berfungsi sebagai kategori referensi (Sekaran \& Bougie, 2013).

\section{Model penelitian}

Analisis yang dilakukan untuk menguji pengaruh dari dewan wanita terhadap kebijakan dividen dilakukan dengan analisis regresi berganda. Pembayaran dividen dihitung dengan menggunakan dividen payout ratio (DIVPR). Pengukuran tersebut sudah banyak digunakan oleh peneliti sebelumnya (Amidu, 2007). Penelitian sebelumnya biasanya dilakukan di negara one-tiers system dimana hanya ada posisi direktur sedangkan penelitian ini menguji dari segi direksi dan komisaris karena Indonesia menerapkan two-tiers system.

Model penelitian untuk menguji hipotesis, sebagai berikut:

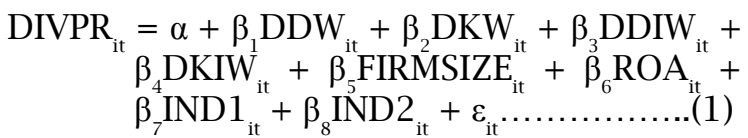

Catatan : DIVPR (Dividend Payout Ratio $)=$ dividen per saham/laba per saham; DDW (Direktur Wanita)= direktur wanita/ total anggota direksi; DKW (Komisaris wanita)=komisaris wanita/total anggota dewan komisaris; DDIW (Direktur Independen Wanita) = direktur independen wanita/total anggota direksi; DKIW (Komisaris Independen Wanita)= komisaris independen wanita/total anggota komisaris; Firmsize (Ukuran Perusahaan)= total aset (log); ROA (Return of Asset)=laba bersih/total aset; IND (Tipe industri) =variabel dummy dengan 3 kelompok.

\section{ANALISIS DAN PEMBAHASAN Statistik Deskriptif}

Pada tabel 2, baik direksi maupun komisaris memiliki jumah wanita yang terus meningkat. Terdapat beberapa alasan yang mendasari peningkatan wanita baik di direksi maupun di komisaris salah satunya dilatarbelakangi oleh adanya globalisasi dan perdagangan lintas batas yang

Tabel 2.

Persentase wanita di direksi dan komisaris

\begin{tabular}{lcccc}
\hline \multicolumn{1}{c}{ Jabatan } & 2013 & 2014 & 2015 & 2016 \\
\hline $\begin{array}{l}\text { Direktur } \\
\text { wanita }\end{array}$ & $14 \%$ & $19 \%$ & $19 \%$ & $19 \%$ \\
$\begin{array}{l}\text { Komisaris } \\
\text { wanita }\end{array}$ & $16 \%$ & $18 \%$ & $23 \%$ & $23 \%$ \\
\hline
\end{tabular}


menghasilkan peningkatan kesadaran kesetaraan gender tenaga kerja, menguraikan adanya norma-norma kemanusiaan yang kerap diserukan oleh organisasi internasional seperti PBB untuk menghapus adanya diskriminasi seperti gender dan warna kulit (Saeed \& Sameer, 2017).

Tabel 3 menunjukkan direktur independen wanita dan komisaris independen wanita terus mengalami peningkatan. Keragaman gender dewan dapat meningkatkan kualitas pengungkapan publik melalui pemantauan yang lebih ketat (Gul, Srinidhi, \& Ng, 2011). Hillman, Cannella Jr, dan Harris (2002) memberikan bukti bahwa sebagian besar direksi wanita berasal dari karir non-bisnis dan menunjukkan kinerja profesional sehingga menyiratkan bahwa wanita tidak memiliki jaringan koneksi dengan pihak lain dan dianggap cocok sebagai pihak independen.

Tabel 3.

Persentase wanita di direktur independen dan komisaris independen

\begin{tabular}{lcccc}
\hline \multicolumn{1}{c}{ Jabatan } & 2013 & 2014 & 2015 & 2016 \\
\hline $\begin{array}{l}\text { Direktur } \\
\text { independen }\end{array}$ & $4 \%$ & $5 \%$ & $5 \%$ & $6 \%$ \\
$\begin{array}{l}\text { wanita } \\
\text { Komisaris } \\
\text { independen } \\
\text { wanita }\end{array}$ & $6 \%$ & $6 \%$ & $9 \%$ & $9 \%$ \\
\hline
\end{tabular}

Tabel 4 menunjukkan nilai rata-rata dan standar deviasi dari semua varibel yang digunakan dalam penelitian ini. Dapat dilihat bahwa rata-rata keseluruhan sampel pada variabel dividen (DIVPR) sebesar 32\% dan nilai rata-rata tertinggi pada tahun 2015 sebesar 34\% sedangkan rata-rata terendah sebesar 30\% pada tahun 2013. Rata-rata keseluruhan pada variabel direktur wanita (DDW) sebesar 19\% dan rata-rata tertinggi sebesar $20 \%$ pada tahun 2016. Rata-rata keseluruhan sampel untuk variabel dewan komisaris wanita (DKW) sebesar 20\% dan rata-rata tertinggi sebesar 24\% pada tahun 2016. Pada variabel direktur independen wanita (DDIW), ratarata keseluruhan sebesar 5\% dan rata-rata pada tahun 2014-2016 cenderung tetap sebesar 6\%. Variabel dewan komisaris independen wanita (DKIW) memiliki ratarata keseluruhan sebesar $8 \%$ dan rata-rata per tahun cenderung konstan sebesar 9\% kecuali tahun 2014 (6\%). Rata-rata keseluruhan pada variabel FIRMSIZE sebesar Rp 18.913.109.836.165 dan rata -rata tertinggi sebesar $\mathrm{Rp}$ 21.675.906.404.536 pada tahun 2015. Variabel ROA memiliki rata-rata keseluruhan sebesar 0,07 dan rata-rata tertinggi pada tahun 2013 sebesar 0,09.

\section{Pengujian Hipotesis}

Tabel 5 menunjukkan hasil pengujian

Tabel 4

Statistik Deskriptif Variabel Penelitian

\begin{tabular}{lcccccccccc}
\hline \multirow{2}{*}{ Variabel } & \multicolumn{2}{c}{ Pooled Data } & \multicolumn{2}{c}{ Tahun 2013 } & \multicolumn{2}{c}{ Tahun 2014} & \multicolumn{2}{c}{ Tahun 2015 } & \multicolumn{2}{c}{ Tahun 2016 } \\
& (138 sampel) & \multicolumn{2}{c}{ (30 sampel) } & \multicolumn{2}{c}{ (37 sampel) } & \multicolumn{2}{c}{ (37 sampel) } & \multicolumn{2}{c}{ (34 sampel) } \\
& Mean & S.D & Mean & S.D & Mean & S.D & Mean & S.D & Mean & S.D \\
\hline DIVPR & 0,32 & 0,17 & 0,30 & 0,16 & 0,31 & 0,16 & 0,34 & 0,17 & 0,32 & 0,20 \\
DDW & 0,19 & 0,17 & 0,18 & 0,17 & 0,18 & 0,18 & 0,20 & 0,18 & 0,20 & 0,17 \\
DKW & 0,20 & 0,16 & 0,15 & 0,16 & 0,18 & 0,16 & 0,23 & 0,16 & 0,24 & 0,15 \\
DDIW & 0,05 & 0,10 & 0,04 & 0,08 & 0,06 & 0,12 & 0,06 & 0,10 & 0,06 & 0,10 \\
DKIW & 0,08 & 0,12 & 0,09 & 0,16 & 0,06 & 0,11 & 0,09 & 0,12 & 0,09 & 0,11 \\
IND1 & 0,70 & 0,46 & 0,70 & 0,47 & 0,70 & 0,46 & 0,70 & 0,46 & 0,71 & 0,46 \\
IND2 & 0,18 & 0,39 & 0,17 & 0,38 & 0,19 & 0,40 & 0,19 & 0,40 & 0,18 & 0,39 \\
& $1,89 \mathrm{E}+$ & $3,49 \mathrm{E}$ & $1,36 \mathrm{E}+$ & $2,63 \mathrm{E}$ & $1,88 \mathrm{E}+$ & $3,46 \mathrm{E}+$ & $2,17 \mathrm{E}$ & $4,07 \mathrm{E}+$ & $2,07 \mathrm{E}+$ & $3,6 \mathrm{E}+$ \\
FIRMSIZE & 13 & +13 & 13 & +13 & 13 & 13 & +13 & 13 & 13 & 13 \\
ROA & 0,07 & 0,05 & 0,09 & 0,06 & 0,08 & 0,06 & 0,06 & 0,04 & 0,06 & 0,04 \\
\hline
\end{tabular}

Catatan : DIVPR (Dividend Payout Ratio; DDW (Proporsi Direktur Wanita); DKW (Proporsi Komisaris wanita); DDIW (Proporsi Direktur Independen Wanita; DKIW (Proporsi Komisaris Independen Wanita); Firmsize (Ukuran Perusahaan); ROA (Return of Asset); IND ( Tipe industri). 
hipotesis dengan menggunakan uji regresi berganda. Panel A dan C menunjukkan adanya hubungan negatif dan signifikan $(p$ value $\leq 0,05)$ antara direktur wanita (DDW) dan pembayaran dividen. Menurut hasil penelitian ini maka H1 dinyatakan diterima. Hasil penelitian ini mendukung penelitian dari Saeed dan Sameer (2017) bahwa keberadaan wanita di direksi berpengaruh negatif terhadap pembayaran dividen. Jadi terbukti bahwa wanita cenderung enggan terhadap risiko karena sifat wanita yang lebih waspada terhadap risiko (Hillman, Shropshire, \& Cannella, 2007). Marter dan Lighthall (2012) menunjukkan bahwa adanya kecenderungan seorang wanita akan merasa takut apabila berada dalam keadaan yang berisiko sehingga mereka akan cenderung untuk menghindari risiko. Adanya ketidakpastian pasar menyebabkan seorang direksi wanita akan cenderung menahan kas dengan cara mengurangi dividen yang dibagikan. Penelitian Ang, Fatemi, dan Tourani-Rad (1997) di Indonesia menunjukkan bahwa perusahaan yang mendapatkan surplus biasanya memiliki laba yang berlimpah dan tak jarang mereka memilih untuk menahan laba untuk diinvestasikan kembali karena pengembalian yang didapat dari pembagian dividen mungkin tidak sebesar apabila laba tersebut diinvestasikan kembali.

Pada tabel 5, Panel A, B dan E variabel komisaris wanita (DKW) justru menunjukkan adanya pengaruh positif signifikan terhadap pembayaran dividen. Hasil pengujian hipotesis menunjukkan bahwa pengaruh keberadaan komisaris wanita dapat meningkatkan jumlah dividen yang dibayarkan. Menurut hasil penelitian maka H2 dinyatakan diterima. Hasil penelitian ini mendukung penelitian Purcheta-Martinez dan Bel-Oms (2015); Chen, Leung, dan Goergen (2017); Byoun, Chang dan Kim (2016); dan Van Pelt (2013) bahwa keberadaan wanita di jajaran dewan komisaris berpengaruh positif terhadap pembayaran dividen. Menurut Wellalage, Fauzi, dan Wang (2012) mengatakan bahwa dewan komisaris yang beragam dapat meningkatkan pembayaran dividen. Wanita dapat membangun saluran komunikasi dan keharmonisan dengan pemangku kepentingan eksternal untuk mengurangi masalah agensi dan mempermudah dalam mengakses sumber daya (Adams \& Ferreira, 2009). Wanita tampaknya juga memiliki keunggulan komparatif sehubungan

Tabel 5.

Hasil Uji Regresi Berganda

\begin{tabular}{|c|c|c|c|c|c|c|c|c|c|c|}
\hline \multirow{4}{*}{ Variabel } & \multirow{3}{*}{\multicolumn{2}{|c|}{$\begin{array}{c}\text { PANEL A } \\
\text { Pooled Data } \\
\text { (138 sampel) }\end{array}$}} & \multirow{3}{*}{\multicolumn{2}{|c|}{$\begin{array}{c}\text { PANEL B } \\
\text { Tahun } 2013 \\
\text { (30 sampel) }\end{array}$}} & \multirow{3}{*}{\multicolumn{2}{|c|}{$\begin{array}{c}\text { PANEL C } \\
\text { Tahun } 2014 \\
\text { (37 sampel) }\end{array}$}} & \multirow{3}{*}{\multicolumn{2}{|c|}{$\begin{array}{c}\text { PANEL D } \\
\text { Tahun } 2015 \\
\text { (37 sampel) }\end{array}$}} & \multirow{3}{*}{\multicolumn{2}{|c|}{$\begin{array}{c}\text { PANEL E } \\
\text { Tahun } 2016 \\
\text { (34 sampel) }\end{array}$}} \\
\hline & & & & & & & & & & \\
\hline & & & & & & & & & & \\
\hline & $\mathrm{t}$ & Sig & $\mathrm{t}$ & Sig & $\mathrm{t}$ & Sig & $\mathrm{t}$ & Sig & $\mathrm{t}$ & Sig \\
\hline DDW & $-2,37$ & $0,02 * *$ & $-1,50$ & 0,15 & $-2,54$ & $0,02 * *$ & $-0,40$ & 0,70 & $-0,12$ & 0,91 \\
\hline DKW & 3,38 & $0,00 * * *$ & 1,80 & $0,09 *$ & 1,25 & 0,22 & 0,54 & 0,59 & 2,00 & $0,06^{*}$ \\
\hline DDIW & 1,18 & 0,24 & 0,52 & 0,61 & 1,56 & 0,13 & 0,81 & 0,42 & $-0,40$ & 0,69 \\
\hline DKIW & $-1,57$ & 0,12 & $-0,55$ & 0,59 & $-0,68$ & 0,50 & $-0,61$ & 0,55 & $-1,60$ & 0,12 \\
\hline IND1 & 0,40 & 0,69 & $-0,01$ & 0,99 & 1,34 & 0,19 & 0,33 & 0,74 & 0,24 & 0,81 \\
\hline IND2 & 0,77 & 0,44 & $-0,19$ & 0,85 & 0,80 & 0,43 & $-0,11$ & 0,92 & 1,15 & 0,26 \\
\hline FIRMSIZE & $-1,10$ & 0,27 & $-0,63$ & 0,54 & $-0,14$ & 0,89 & $-1,07$ & 0,29 & $-0,61$ & 0,55 \\
\hline ROA & 2,83 & $0,01 * *$ & 0,44 & 0,66 & 2,67 & $0,01^{* * *}$ & 1,96 & $0,06^{*}$ & 0,60 & 0,55 \\
\hline
\end{tabular}

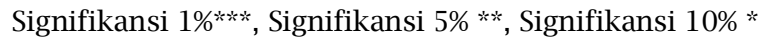

Catatan : DIVPR (Dividend Payout Ratio)=dividen per saham/laba per saham; DDW (Proporsi Direktur Wanita) =proporsi direktur wanita/total anggota direksi; DKW (Proporsi Komisaris wanita)=proporsi komisaris wanita/ total anggota dewan komisaris; DDIW (Proporsi Direktur Independen Wanita)= proporsi direktur independen wanita/total anggota direksi; DKIW (Proporsi Komisaris Independen Wanita)=proporsi komisaris independen wanita/total anggota komisaris; Firmsize (Ukuran Perusahaan)= total aset (log); ROA (Return of Asset)=laba bersih/total aset; IND ( Tipe industri)=variabel dummy dengan 3 kelompok. 
dengan diversifikasi produk dan tugastugas yang berhubungan dengan komunikasi (Schubert, 2006). Adanya keharmonisan dengan para pemegang saham menyebabkan komisaris mengerti apa yang diinginkan pemegang saham dan bertindak demi kepentingan perusahaan maupun para pemangku kepentingan.

Tampak pada Panel A, B, C, D, dan E (tabel 3), variabel direksi independen wanita (DDIW) tidak berpengaruh terhadap pembayaran dividen, maka H3 dinyatakan ditolak. Variabel dewan komisaris independen wanita (DKIW) juga menunjukkan tidak ada pengaruh terhadap pembayaran dividen, maka $\mathrm{H} 4$ dinyatakan ditolak. Berdasarkan penelitian Darmadi (2013), direktur dan komisaris independen kurang independen karena di Indonesia didominasi oleh perusahaan keluarga sehingga kontrol dari pihak keluarga mendominasi dalam proses pengambilan keputusan sehingga sulit untuk bertindak independen dan kontribusi pihak independen dalam pengambilan keputusan terbatas. Para pihak independen mungkin tidak memiliki mandat, insentif dan kemampuan untuk memantau secara ketat (Gutierrez \& Sáez, 2012).

Variabel kontrol terdiri atas tipe industri, ukuran perusahaan (firmsize), dan ROA. Panel A, B, C, D, dan E menunjukkan tipe industri dan ukuran perusahaan tidak berpengaruh terhadap pembayaran dividen, sedangkan variabel ROA menunjukkan pengaruh positif signifikan seperti yang ditunjukkan oleh Panel A, C, dan D (Tabel 5). Jadi, semakin baik kemampuan perusahaan dalam menghasilkan laba dari aset maka mereka akan memberikan dividen yang lebih tinggi.

\section{KESIMPULAN DAN IMPLIKASI \\ Kesimpulan}

Penelitian ini bertujuan untuk menguji pengaruh keragaman gender baik di direksi maupun di dewan komisaris terhadap kebijakan dividen. Kebijakan dividen di proksikan dengan dividend payout ratio. Penelitian ini menggunakan 138 sampel dari semua sektor yang terdaftar di Bursa Efek Indonesia selama tahun 2013-2016. Penelitian ini menunjukkan bahwa keberadaan direksi wanita berpengaruh signifikan negatif terhadap pembayaran dividen sedangkan semakin banyak wanita di komisaris berpengaruh positif terhadap jumlah dividen yang dibayarkan. Jadi, semakin banyak wanita di direksi dapat mengurangi pembayaran dividen karena direktur wanita cenderung mengurangi risiko ketika terjadi ketidakpastian. Namun, peran wanita sebagai komisaris justru dapat meningkatkan pembayaran dividen karena komisaris wanita akan menuntut lebih banyak mekanisme kontrol terhadap manajemen serta membuat keputusan yang berdampak positif bagi pemegang saham salah satunya dengan membayarkan dividen tersebut. Direksi independen wanita dan komisaris independen wanita tidak berpengaruh terhadap pembayaran dividen. Baik direktur independen wanita maupun komisaris independen wanita tidak memiliki pengaruh karena sebagian besar perusahaan di Indonesia dimiliki oleh beberapa keluarga. Kontrol keluarga yang mendominasi menyebabkan sulit bagi pihak independen untuk bertindak independen. Direktur independen dan komisaris independen belum mampu untuk memberikan pemantauan secara efektif kepada manajemen sehingga terdapat kemungkinan munculnya masalah agensi.

\section{Implikasi}

Kesetaraan gender di dunia kerja masih banyak disoroti baik organisasi domestik maupun internasional. Oleh karena itu, penelitian ini merekomendasikan agar perusahaan memperbanyak keragaman gender di tingkat manajemen agar tercipta sistem pengambilan kebijakan yang lebih baik khususnya terkait dividen. Selain itu, perusahaan juga harus lebih memperhatikan dan meningkatkan independensi baik direksi maupun komisaris agar mereka dapat menyuarakan hak-hak para pemegang saham seperti hak untuk mendapatkan dividen. Kemudian, pemerintah diharapkan juga mendorong adanya kesetaraan gender tenaga kerja untuk menciptakan kesadaran akan manfaat keberagaman gender di jajaran 
dewan.

\section{KETERBATASAN DAN SARAN \\ Keterbatasan}

Pada penelitian ini memiliki beberapa keterbatasan, seperti sampel yang terbatas sebab pembayaran dividen bukanlah suatu keharusan. Perusahaan akan membagikan dividen apabila mendapatkan laba dan dapat menyisihkan sekitar 20\% untuk dijadikan dana cadangan. Terlebih lagi, wanita juga masih menjadi kaum minoritas di jajaran dewan baik direksi maupun dewan komisaris. Terdapat kemungkinan apabila jumlah data yang tersedia lebih banyak maka hubungan linear antara keragaman gender dan dividen mungkin akan berubah. Mengingat penelitian ini hanya menggunakan informasi yang tersedia di laporan tahunan dan laporan keuangan maka sulit untuk menentukan apakah keberadaan wanita benar-benar dapat menghasilkan keputusan yang berbeda dengan anggota yang dominasi pria terkait keputusan pembayaran dividen. Diperlukan adanya observasi lebih lanjut untuk dapat memahami perbedaan perilaku antara wanita dan pria dalam mengambil keputusan.

\section{Saran}

Penulis menyarankan beberapa hal bagi penelitian selanjutnya, seperti melakukan perbandingan dengan negara lain karena terdapat kemungkinan setiap negara berkembang memiliki keadaan perekonomian yang berbeda sehingga memungkinkan keputusan yang diambil oleh seorang direktur wanita dan komisaris wanita akan berbeda sesuai dengan keadaan lingkungan yang dihadapi.

\section{DAFTAR PUSTAKA}

Adams, R.B., \& Ferreira, D. (2009). Women in the boardroom and their impact of governance and performance. Journal of Financial Economics, 94(2), 291309.

Adams, R.B., \& Funk, P. (2012). Beyond the glass ceiling: Does gender matter? Management science, 58(2), 219-235.

Adams, R.B., Hermalin., \& Weisbach. (2010). The role of boards of directors in corporate governance: A conceptual framework and survey. Journal of
Economic Literature, 48(1), pages 58107.

Amason, A.C. (1996). Distinguishing the effects of functional and dysfunctional conflict on strategic decision making: Resolving a paradox for top management teams. Academy of management journal, 39(1), 123148.

Amidu., J.A. (2006). Determinants of dividend payout ratios in Ghana. The Journal of Risk Finance, 7(2), 136 145.

Andrés, P., Arranz-Aperte, L., \& RodriguezSanz, J,A. (2017). Independent versus non-independent outside directors in European companies: Who has a say on CEO compensation?. BRQ Business Research Quarterly, 20(2), 79-95.

Ang, J., Fatemi, A., \& Tourani-Rad, A. (1997). Capital structure and dividend policies of Indonesian firms. Pacific-Basin Finance Journal, 5(1), 87 $-103$.

Bear, S., Rahman, N., \& Post, C. (2010). The impact of board diversity and gender composition on corporate social responsibility and firm reputation. Journal of Business Ethics, 97(2), 207221.

Ben-Nasr, H. (2015). Government ownership and dividend policy: Evidence from newly privatized firms. Journal of Business Finance \& Accounting, 42(5), 665-704.

Bermig, A., \& Frick, B. (2010). Board size, board composition, and firm performance: Empirical evidence from Germany. Diakses dari https:// ssrn.com/abstract $=1623103$

Byoun, S., Chang, K., \& Kim, Y.S. (2016). Does corporate board diversity affect corporate payout policy?. Asia-Pacific Journal of Financial Studies, 45(1), 48101.

Cabo, R., Gimeno, R., \& Nieto, M. (2012). Gender Diversity on European Banks' Boards of Directors. Journal of Business Ethics 109, 145-162

Chen, G., Liu, C., \& Tjosvold, D. (2005). Conflict management for effective top management teams and innovation in China. Journal of Management Studies, 42(2), 277-300.

Chen, J., Leung, W.S., \& Goergen, M. (2017). The impact of board gender composition on dividend payouts. Journal of Corporate Finance, 43, 86105.

Darmadi, S. (2013). Do women in top management affect firm 
performance? Evidence from Indonesia. Corporate Governance: The international journal of business in society, 13(3), 288-304.

Eckel, C.C. \& Grossman, P.J. 2008. Men, women and risk aversion: Experimental evidence. Handbook of experimental economics results, 1 (113), 1061-1073.

Erhardt, N.L., Werbel, J.D., \& Shrader, C.B. (2003). Board of director diversity and firm financial performance. Corporate governance: An international review, 11(2), 102-111.

Ferry, K. (2016). Diversity Scorecard 2016 : Building Diversity In Asia Pasific Boardroom.

Fombrun, C.J., \& Pan, M. (2006). Corporate reputations in China: How do consumers feel about companies?. Corporate Reputation Review, 9(3), 165-170.

Gul, F.A., Srinidhi, B., \& Ng, A.C. (2011). Does board gender diversity improve the informativeness of stock prices?. Journal of Accounting and Economics, 51(3), 314-338.

Gutiérrez, M., \& Sáez, M. (2013). Deconstructing independent directors. Journal of Corporate Law Studies, 13(1), 63-94.

Hillman, A.J., Cannella, A.A.,\& Paetzold, R.L. (2000). The resource dependence role of corporate directors: Strategic adaptation of board composition in response to environmental change. Journal of Management studies, 37(2): 235-256.

Hillman, A.J., Shropshire, C., \& Cannella, A.A. (2007). Organizational predictors of women on corporate boards. Academy of Management Journal, 50(4), 941-952.

Hillman, A.J., Cannella Jr, A.A., \& Harris, I.C. (2002). Women and racial minorities in the boardroom: how do directors differ?. Journal of Management ,28, 747.

Holmstrom, B., \& Milgrom, P. (1994). The Firm as an incentive system. The American Economic Review, 84(4), 972-991.

Jensen, M., \& Meckling, W. (1976). The theory of the firm: managerial behavior, agency costs and ownership structure. Journal Finance and Economic, 3, 305-360.

Jensen, M.C. (1986). Agency costs of free cash flow corporate finance, and takeovers. American Economic Review, 76(2), 323-329.
Kusumastuti, S., Supatmi, S., \& Sastra, P. (2008). Pengaruh board diversity terhadap nilai perusahaan dalam perspektif corporate governance. Jurnal Akuntansi dan Keuangan, 9(2), 88-98.

La Porta, R., Lopez-de-Silanes, F., Shleifer, A., \& Vishny, R.W. (2000). Agency problems and dividend policies around the world. The Journal of Finance, 55(1), 1-33.

Mather, M., \& Lighthall, N.R. (2012). Risk and reward are processed differently in decisions made under stress. Current Directions in Psychological Science, 21(1), 36-41.

Prasanna, P.K. (2014). Firm-level governance quality and dividend decisions: evidence from India. International Journal of Corporate Governance, 5(3), 197-222.

Probohudono, A.N., Tower, G., \& Rusmin, R. (2013). Risk disclosure during the global financial crisis. Social Responsibility Journal, 9(1), 124-137.

Pucheta-Martínez, M.C., \& Bel-Oms, I. (2015). The board of directors and dividend policy: The effect of gender diversity. Industrial and Corporate Change, 25(3), 523-547.

Saeed, A., \& Sameer, M. (2017). Impact of board gender diversity on dividend payments: Evidence from some emerging economies. International Business Review, 26(6), 1100-1113.

Saeed, A., Belghitar, Y., \& Yousaf, A. (2016). Firm-level determinants of gender diversity in the boardrooms: Evidence from some emerging economies. International Business Review, 25(5), 1076-1088.

Schubert, R. (2006). Analyzing and managing risks - on the importance of gender differences in risk attitudes. Managerial Finance, 32(9), $706-715$.

Sekaran, U., \& Bougie. (2013). Edisi 5, Research Methods for Business: A skill Building Approach. New York: John wiley.

Sharma, V. (2011). Independent directors and the propensity to pay dividends. Journal of Corporate Finance, 17(4), 1001-1015.

Thornton, G. (2015). Women in business: the path to leadership. Grant Thornton International Business Report.

Undang-undang Nomor 40 Tahun 2007 Perseroan Terbatas. 16 Agustus 2007. Lembaran Negara Republik Indonesia 
Direksi Dan Dewan Komisaris: Pengaruh Dewan Wanita Terhadap Kebijakan Dividen Di Indonesia (Fauziah dan Probohudono)

Tahun 2007 Nomor 106. Jakarta.

Van Pelt, T. (2013). The effect of board characteristics on dividend policy. Unpublished working paper, Tilburg School of Economics and Management, Department of Finance. Tilburg University: The Netherlands, 1 $-62$.

Ward, A., \& Forker, J. (2015). Financial Management Effectiveness and Board
Gender Diversity in Member-

Governed, Community Financial

Institutions. Journal of Business Ethics, 141(2), 351-366.

Wellalage, N., Fauzi, F., \& Wang, G. (2012).

Corporate governance and cash dividend policy: Evidence from Chinese IPOs. Unpublished working paper, 1-24. 